\title{
Characterization of the inflammatory and metabolic profile of adipose tissue in a mouse model of chronic hypoxia.
}

Citation for published version (APA):

van den Borst, B., Schols, A. M. W. J., de Theije, C. C., Boots, A. W., Köhler, S. E., Goossens, G. H., \& Gosker, H. R. (2013). Characterization of the inflammatory and metabolic profile of adipose tissue in a mouse model of chronic hypoxia. Journal of Applied Physiology, 114(11), 1619-1628.

https://doi.org/10.1152/japplphysiol.00460.2012

Document status and date:

Published: 01/06/2013

DOI:

10.1152/japplphysiol.00460.2012

Document Version:

Publisher's PDF, also known as Version of record

\section{Document license:}

Taverne

Please check the document version of this publication:

- A submitted manuscript is the version of the article upon submission and before peer-review. There can be important differences between the submitted version and the official published version of record.

People interested in the research are advised to contact the author for the final version of the publication, or visit the DOI to the publisher's website.

- The final author version and the galley proof are versions of the publication after peer review.

- The final published version features the final layout of the paper including the volume, issue and page numbers.

Link to publication

\footnotetext{
General rights rights.

- You may freely distribute the URL identifying the publication in the public portal. please follow below link for the End User Agreement:

www.umlib.nl/taverne-license

Take down policy

If you believe that this document breaches copyright please contact us at:

repository@maastrichtuniversity.nl

providing details and we will investigate your claim.
}

Copyright and moral rights for the publications made accessible in the public portal are retained by the authors and/or other copyright owners and it is a condition of accessing publications that users recognise and abide by the legal requirements associated with these

- Users may download and print one copy of any publication from the public portal for the purpose of private study or research.

- You may not further distribute the material or use it for any profit-making activity or commercial gain

If the publication is distributed under the terms of Article 25fa of the Dutch Copyright Act, indicated by the "Taverne" license above, 


\title{
Characterization of the inflammatory and metabolic profile of adipose tissue in a mouse model of chronic hypoxia
}

\author{
Bram van den Borst, ${ }^{1}$ Annemie M. W. J. Schols, ${ }^{1}$ Chiel de Theije, ${ }^{2}$ Agnes W. Boots, ${ }^{3}$ S. Eleonore Köhler, ${ }^{2}$ \\ Gijs H. Goossens, ${ }^{4}$ and Harry R. Gosker ${ }^{1}$ \\ ${ }^{1}$ Department of Respiratory Medicine, NUTRIM School for Nutrition, Toxicology and Metabolism, Maastricht University \\ Medical Center, Maastricht, The Netherlands; ${ }^{2}$ Department of Anatomy \& Embryology, NUTRIM School for Nutrition, \\ Toxicology and Metabolism, Maastricht University Medical Center, Maastricht, The Netherlands; ${ }^{3}$ Department of Toxicology, \\ NUTRIM School for Nutrition, Toxicology and Metabolism, Maastricht University Medical Center, Maastricht, The \\ Netherlands; ${ }^{4}$ Department of Human Biology, NUTRIM School for Nutrition, Toxicology and Metabolism, Maastricht \\ University Medical Center, Maastricht, The Netherlands
}

Submitted 10 April 2012; accepted in final form 25 March 2013

van den Borst B, Schols AM, de Theije C, Boots AW, Köhler SE, Goossens GH, Gosker HR. Characterization of the inflammatory and metabolic profile of adipose tissue in a mouse model of chronic hypoxia. J Appl Physiol 114: 1619-1628, 2013. First published March 28, 2013; doi:10.1152/japplphysiol.00460.2012.—In both obesity and chronic obstructive pulmonary disease (COPD), altered oxygen tension in adipose tissue (AT) has been suggested to evoke AT dysfunction, subsequently contributing to metabolic complications. Studying the effects of chronic hypoxia on AT function will add to our understanding of the complex pathophysiology of alterations in AT inflammation, metabolism, and mass observed in both obesity and COPD. This study investigated the inflammatory and metabolic profile of AT after chronic hypoxia. Fifty-two-week-old C57B1/6J mice were exposed to chronic hypoxia $\left(8 \% \mathrm{O}_{2}\right)$ or normoxia for 21 days, after which AT and plasma were collected. Adipocyte size, AT gene expression of inflammatory and metabolic genes, AT macrophage density, and circulating adipokine concentrations were measured. Food intake and body weight decreased upon initiation of hypoxia. However, whereas food intake normalized after 10 days, lower body weight persisted. Chronic hypoxia markedly reduced AT mass and adipocyte size. AT macrophage density and expression of Emrl, Ccl2, Lep, and Tnf were decreased, whereas Serpinel and Adipoq expression levels were increased after chronic hypoxia. Concomitantly, chronic hypoxia increased AT expression of regulators of oxidative metabolism and markers of mitochondrial function and lipolysis. Circulating IL-6 and PAI-1 concentrations were increased, and leptin concentration was decreased after chronic hypoxia. Chronic hypoxia is associated with decreased rather than increased AT inflammation, and markedly decreased fat mass and adipocyte size. Furthermore, our data indicate that chronic hypoxia is accompanied by significant alterations in AT metabolic gene expression, pointing toward an enhanced AT metabolic rate.

inflammation; COPD; oxidative metabolism; lipolysis

OBESITY AND CHRONIC OBSTRUCTIVE pulmonary disease (COPD) are two major chronic conditions with high prevalence worldwide $(1,27)$, and are increasingly occurring together $(7,42)$. In obesity, both decreased and increased oxygen tension within the adipose tissue (AT) have been suggested to contribute to AT dysfunction and inflammation, which may subsequently increase the risk for metabolic complications $(9,10,23,37)$.

Address for reprint requests and other correspondence: B. van den Borst, Dept. of Respiratory Medicine, NUTRIM School for Nutrition, Toxicology and Metabolism, Maastricht Univ. Medical Center, PO Box 616, 6200 MD, Maastricht, The Netherlands (e-mail: b.vdborst@maastrichtuniversity.nl).
Chronic hypoxemia in COPD, on the other hand, accelerates loss of body and fat masses, in part by increasing the resting metabolic rate $(29,33,43)$. However, the effects of chronic hypoxia on AT function remain incompletely understood. Studying the effects of chronic hypoxia on AT function is important because it may add to our understanding of the complex pathophysiology of alterations in AT inflammation, metabolism and mass observed in both obesity and COPD.

It is now well established that AT is an inflammatory and metabolically active tissue (8). Hypoxia may induce AT dysfunction and inflammation via direct effects of low $\mathrm{Pa}_{2}$, endoplasmic reticulum stress, oxidative stress, or other mechanisms (37). In obesity, the combination of hypertrophying adipocytes and insufficient neovascularization may lead to local hypoxic tissue areas and to hypoxia within large adipocytes lying distant from capillaries (39). Indeed, in various mouse models of obesity, local areas of hypoxia were demonstrated in the AT $(14,31,46)$. This was accompanied by increased AT expression of hypoxia-responsive markers [e.g., glucose transporter (GLUT)-1 (31, 46), vascular endothelial growth factor (VEGF) (46)], altered adipokine mRNA expression [e.g., increased leptin and plasminogen activator-inhibitor (PAI)-1, decreased adiponectin (14)], increased mRNA expression of proinflammatory markers [e.g., tumor necrosis factor (TNF)- $\alpha$, interleukin (IL)-6 (46)], and increased expression and presence of $\mathrm{F} 4 / 80+$ macrophages in the AT $(31,46)$. To further substantiate the potential direct role of hypoxia on adipocyte inflammation, many in vitro studies have been carried out in which either murine (mostly 3T3-L1 cells) or human adipocytes were exposed to hypoxia. Although these studies used exposure to extreme, nonphysiological $\mathrm{Pa}_{\mathrm{O}_{2}}\left(1 \% \mathrm{O}_{2}\right)$, the majority of these studies have indeed reported gross hypoxiainduced changes rendering adipocytes more proinflammatory and altering their adipokine expression and secretion profiles $(14,19,45,46,48)$. Importantly, however, conflicting data have also been reported $(5,9)$. It has been demonstrated that chronic hypoxia substantially lowered the inflammatory response in primary human adipocytes (5), and $\mathrm{Pa}_{\mathrm{O}_{2}}$ in abdominal subcutaneous AT was inversely associated with the expression of inflammatory markers in this fat depot (9).

The physiological cellular response to hypoxia includes switching from oxidative to anaerobic metabolism. In vitro studies have indeed shown increased expression of various glucose transporters and other markers of glycolytic metabolism and decreased expression of mitochondrial components 
and their major upstream regulator, peroxisome proliferatoractivated receptor (PPAR)- $\gamma$ coactivator-1 $\alpha$ (PGC-1 $\alpha$ ) (19). This shift would imply increased lactate production from adipocytes, which is indeed observed in obesity (2) and after hypoxia (24). Studies investigating the effect of altered oxygen tension on lipolysis have yielded conflicting results. Both extreme hypoxia $\left(1 \% \mathrm{O}_{2}\right)(47)$ and hyperoxia $\left(95 \% \mathrm{O}_{2}\right)(28)$ enhanced lipolysis in 3T3-L1 adipocytes.

Chronic hypoxemia as a consequence of COPD may also affect AT function. Recent studies have detected increased mRNA expression of the proinflammatory markers CD40, MAPK kinase 4, and c-Jun $\mathrm{NH}_{2}$-terminal kinase (36) and increased expression of inhibitors of nuclear factor- $\kappa \mathrm{B}(35)$ in abdominal subcutaneous AT biopsies from hypoxemic, underweight patients with COPD compared with normoxemic, overweight patients with COPD.

Although the data on the causal role of hypoxia on AT dysfunction and inflammation appear robust, there are several limitations that call for more research. Whereas AT hypoxia in obesity is chronic (37), the in vitro studies cited above investigated hypoxia exposures of 2-24 h, which induced acute effects. In addition, the level of hypoxia applied in these studies was very extreme $\left(1 \% \mathrm{O}_{2}\right)$, which does not reflect physiological AT oxygen tension in obesity $\left(3-11 \% \mathrm{O}_{2}\right)(10)$. Third, given that immune cells within the AT play an important role in (co-) driving AT dysfunction in obesity (20), an in vivo model is the preferred model to allow for the interaction of different cell types under hypoxic conditions. For these reasons, we designed a model in which we exposed mice to 21 days of hypoxia $\left(8 \% \mathrm{O}_{2}\right)$. This allowed us to investigate whether the acute inflammatory and metabolic alterations observed with acute, severe hypoxia also persist in a chronic model with more physiologically relevant levels of hypoxia.

\section{MATERIALS AND METHODS}

Experimental procedure. Fifty-two-week-old male C57BL/6J mice (Charles River Laboratories, Wilmington, MA) were exposed to ambient air (normoxia, $n=8$ ) or chronic hypoxia $(n=8)$ for 21 days. We studied 52-wk-old mice, rather than the more commonly studied young adult but not fully-grown 12-wk-old mice, to preclude increasing body weight (and expanding fat mass) as a confounder. Mice at age 52 wk remain weight-stable under control conditions. All mice were housed in experimental chambers at $21^{\circ} \mathrm{C}$ with a 12 -h dark/light cycle. Mice received standard chow (V1534-000 ssniff R/M-H, ssniff Spezialdiäten, Soest, Germany) and water ad libitum. Using the proOX P110 (BioSpherix, Lacona, NY) system, $\mathrm{O}_{2}$ was replaced by $\mathrm{N}_{2}$ in a stepwise manner to create normobaric oxygen levels of $12 \%$ (day 1$), 10 \%$ (day 2), and finally $8 \%(60.8 \mathrm{mmHg})$ on day 3 . The latter oxygen concentration was maintained for the remainder of the experiment. Three to four mice were housed per cage. Daily food intake was determined per cage, and mice were weighed daily. On day 21, mice were anesthetized with isoflurane gas, the abdominal cavity was opened, and aortic blood was collected into a heparin-coated 1-ml syringe (Becton Dickinson, Breda, The Netherlands). Oxygen levels and $\mathrm{pH}$ were measured immediately using the ABL 510 Blood Gas Analyzer (Radiometer; Diamond Diagnostics, Holliston, MA) and blood cell count was determined with the Coulter Ac T Diff hematology Analyzer (Beckman Coulter, Woerden, The Netherlands). Plasma was stored at $-80^{\circ} \mathrm{C}$ until further analyses. Visceral adipose tissue (VAT, epididymal) and subcutaneous adipose tissue (SCAT, inguinal) pads were collected bilaterally and weighed. One specimen of each was fixed in $4 \%$ formaldehyde, transferred to $70 \%$ ethanol, and subsequently embedded in paraffin. The other was snap-frozen in liquid nitrogen and stored at $-80^{\circ} \mathrm{C}$ for later mRNA analyses. Lower limb skeletal muscles (gastrocnemius, tibialis anterior, soleus, extensor digitorum longus, and plantaris), liver, and spleen were dissected and weighed. Two normoxic mice were excluded because of infection. The protocol was approved by the Committee for Animal Care and Use of Maastricht University (project 2009-151).

Plasma adipokine assays. Plasma adipokine profiles were determined using the Luminex xMAP-technology (32). A Bio-Plex (BioRad, Veenendaal, The Netherlands) murine cytokine 6-plex panel was used to quantify the concentrations of interleukin (IL)-1 $\beta$, IL-6, keratinocyte-derived chemokine (KC), monocyte chemotactic protein (MCP)-1, tumor necrosis factor (TNF)- $\alpha$, and chemokine (C-C motif) ligand 5 (CCL5). Additionally, three independent single-plex panels were executed to assess the concentrations of leptin, adiponectin, and plasminogen activator-inhibitor (PAI)-1. All assays were performed according to manufacturer instructions. Data analysis was performed with a Luminex 100 IS 2.3 system (Luminex, Austin, TX) using the Bio-Plex Manager 4.1.1 software (Bio-Rad). The lower limits of detection (LLOD) of the cytokines and adipokines measured were $0.74 \mathrm{pg} / \mathrm{ml}$ for IL-6, $3.4 \mathrm{pg} / \mathrm{ml}$ for TNF- $\alpha, 3.3 \mathrm{pg} / \mathrm{ml}$ for IL- $1 \beta, 1.9$ $\mathrm{pg} / \mathrm{ml}$ for KC, $23.7 \mathrm{pg} / \mathrm{ml}$ for CCL5, $2.4 \mathrm{pg} / \mathrm{ml}$ for MCP-1, $0.7 \mathrm{ng} / \mathrm{ml}$ for leptin, $6.5 \mathrm{pg} / \mathrm{ml}$ for PAI-1, and $6.5 \mu \mathrm{g} / \mathrm{ml}$ for adiponectin. Cytokine concentrations for the measurements below the LLOD were computed using a maximum-likelihood estimation procedure $(18,44)$, which was required for the IL- 6 and $\mathrm{KC}$ data. It is well established that simpler methods such as assuming the value of one-half of the LLOD or omitting undetectable samples from analyses generate biased estimates of the measures (13). Reproducibility statistics based on computed data, on the other hand, are approximately unbiased when less than half of the measurements are below the LLOD (18) as was the case in our study.

Adipocyte size. VAT and SCAT paraffin sections $(4 \mu \mathrm{m})$ were stained with hematoxylin-eosin, and nonoverlapping fields were photographed at $200 \times$ magnification (Nikon Eclipse E800; Nikon Instruments Europe, Amsterdam, The Netherlands). The areas of $\geq 400$ unique adipocytes per fat pad were measured using computerized software (Lucia GF, Version 4.81; Laboratory Imaging, Prague, Czech Republic).

$R T-q P C R$ analysis. Total RNA from VAT and SCAT was extracted with the Rneasy Lipid Tissue Mini Kit (Qiagen, Venlo, The Netherlands) and reverse-transcribed into cDNA using the Transcriptor cDNA synthesis kit (Roche Applied Sciences, Mannheim, Germany). Complementary DNA was amplified using Sensimix SYBR \& Fluorescein Kit (GC Biotech, Alphen a/d Rijn, The Netherlands) on a quantitative PCR machine (Bio-Rad). Table 1 presents an overview of the target genes and primer sequences. Expression levels of target genes were normalized for the expression of three stable housekeeping genes (Ppia, Axin1, and Canx) using GeNorm software (Primerdesign, Southampton, NY) (41).

Immunohistochemistry. Deparaffinized 4- $\mu \mathrm{m}$-thick sections of VAT and SCAT were incubated with the antibody AIA31240 (SanBio, Uden, The Netherlands) directed against macrophages (26). Macrophages were quantified on microscopic pictures at $200 \times$ magnification, and macrophage density was expressed as the number of macrophages per 100 adipocytes. If crown-like structures (CLS; aggregations of single or fused macrophages around a single adipocyte) were encountered, their density was expressed as number of CLS per 100 adipocytes.

Statistics. Differences between mice exposed to chronic hypoxia or to normoxia were tested using Student's $t$-tests or Mann-Whitney $U$-tests as appropriate. Body weight changes during the experiment were tested using repeated measures ANOVA. Differences in the responses between VAT and SCAT were tested using linear regression analyses in which the interaction term of condition (normoxia vs. hypoxia) and adipose depot (VAT vs. SCAT) were evaluated for statistical significance. Correlations were tested using Pearson's correlation coefficient, $r$. Data are presented as means \pm SE. Analyses 
Table 1. Gene names, proteins encoded by the genes, and primer sequences

\begin{tabular}{|c|c|c|c|}
\hline Gene & $\begin{array}{l}\text { Protein Encoded } \\
\text { by the Gene }\end{array}$ & Forward Primer $\left(5^{\prime}-3^{\prime}\right)$ & Reverse Primer $\left(5^{\prime}-3^{\prime}\right)$ \\
\hline \multicolumn{4}{|l|}{ Hypoxia } \\
\hline Vascular endothelial growth factor A (Vegfa) & VEGF-A & CTGTACCTCCACCATGCCAAGT & TCGCTGGTAGACATCCATGAACT \\
\hline $\begin{array}{l}\text { Solute carrier family } 2 \text { (facilitated glucose } \\
\text { transporter), member } 1 \text { (Slc2a1) }\end{array}$ & GLUT-1 & TGACCATCGCCCTGGCCT & GGACCAGGGCCTACTTCAAAGAAG \\
\hline $\begin{array}{l}\text { 6-phosphofructo-2-kinase/fructose-2,6- } \\
\text { biphosphatase } 3 \text { (Pfkfb3) }\end{array}$ & PFKFB3 & AGAACTTCCACTCTCCCACCCAAA & AGGGTAGTGCCCATTGTTGAAGGA \\
\hline \multicolumn{4}{|l|}{ Macrophages } \\
\hline $\begin{array}{l}\text { EGF-like module containing, mисin-like, } \\
\quad \text { hormone receptor-like sequence } 1 \text { (Emr1) }\end{array}$ & $\mathrm{F} 4 / 80$ & GGATGTACAGATGGGGGATG & CATAAGCTGGGCAAGTGGTA \\
\hline Chemokine (C-C motif) ligand 2 (Ccl2) & MCP-1 & CCTGCTGTTCACAGTTGCC & ATTGGGATCATCTTGCTGGT \\
\hline \multicolumn{4}{|l|}{ Adipocytokines } \\
\hline Tumor necrosis factor (Tnf) & TNF- $\alpha$ & CAGCGCTGAGGTCAATCTGCC & TGCCCGGACTCCGCAA \\
\hline Interleukin 6 (Il6) & IL-6 & ATGGATCCTACCAAACTGGAT & TGAAGGACTCTGGCTTTGTCT \\
\hline Interleukin 1 beta $(I l 1 b)$ & IL-1 $\beta$ & GTAATGAAAGACGGCACACCCAC & CCGTTTTTCCATCTTCTTCTTTGG \\
\hline Interleukin 10 (Il10) & IL-10 & CCAAGCCTTATCGGAAATGA & TTTTCACAGGGGAGAAATCG \\
\hline Leptin (Lep) & Leptin & CAAGCAGTGCCTATCCAGA & AAGCCCAGGAATGAAGTCCA \\
\hline $\begin{array}{l}\text { Adiponectin, } C 1 Q \text { and collagen domain } \\
\text { containing (Adipoq) }\end{array}$ & Adiponectin & TGTTCCTCTTAATCCTGCCCA & CCAACCTGCACAAGTTCCCTT \\
\hline $\begin{array}{l}\text { Serine (or cysteine) peptidase inhibitor, } \\
\text { clade E, member } 1 \text { (Serpine1) }\end{array}$ & PAI-1 & GCСTCCTCATCCTGCCTAA & GCCAGGGTTGCACTAAACAT \\
\hline \multicolumn{4}{|l|}{ Oxidative metabolism } \\
\hline $\begin{array}{l}\text { Peroxisome proliferative activated receptor, } \\
\text { gamma, coactivator } 1 \text { alpha (Ppargcla) }\end{array}$ & PGC- $1 \alpha$ & CAACAATGAGCCTGCGAACA & CTTCATCCACGGGGAGACTG \\
\hline $\begin{array}{l}\text { Peroxisome proliferative activated receptor, } \\
\text { gamma, coactivator } 1 \text { beta }(\text { Ppargclb) }\end{array}$ & PGC-1 $\beta$ & ACCCTGAGAAAGCGCAATGA & CCCAGATGAGGGAAGGGACT \\
\hline Transcription factor A, mitochondrial (Tfam) & TFAM & CCGGCAGAGACGGTTAAAAA & TCATCCTTTGCCTCCTGGAA \\
\hline Cytochrome c-1 (Cycl) & Cytochromec-1 & GCATTCGGAGGGGTTTCCAG & CCGCATGAACATCTCCCCA \\
\hline $\begin{array}{l}\text { Uncoupling protein } 1 \text { (mitochondrial, proton } \\
\text { carrier) (Ucp1) }\end{array}$ & UCP-1 & GCGTACCAAGCTGTGCGATG & GACGTTCCAGGACCCGAGTC \\
\hline Adrenergic receptor, beta 3 (Adrb3) & $\beta_{3}-\mathrm{AR}$ & AGGCAACCTGCTGGTAATCA & TCCACAGTTCGCAACCAGTT \\
\hline $\begin{array}{l}\text { Cell death-inducing DNA fragmentation } \\
\text { factor, alpha subunit-like effector A }\end{array}$ & Cidea & TGCTCTTCTGTATCGCCCAGT & GCCGTGTTAAGGAATCTGCTG \\
\hline \multicolumn{4}{|l|}{ Lipid metabolism } \\
\hline $\begin{array}{l}\text { Peroxisome proliferator activated receptor } \\
\text { gamma (Pparg) }\end{array}$ & PPAR- $\gamma$ & CGGAAGCCCTTTGGTGACTT & TGGGCTTCACGTTCAGCAAG \\
\hline $\begin{array}{l}\text { Sterol regulatory element-binding protein } 1 c \\
\quad(\text { Srebp } 1 c)\end{array}$ & SREBP-1c & GATGTGCGAACTGGACACAG & CATAGGGGGCGTCAAACAG \\
\hline Lipase, hormone sensitive (Lipe) & HSL & CAGAAGGCACTAGGCGTGATG & GGGCTTGCGTCCACTTAGTTC \\
\hline $\begin{array}{l}\text { Patatin-like phospholipase domain } \\
\text { containing } 2 \text { (Pnpla2) }\end{array}$ & ATGL & CAACGCCACTCACATCTACGG & GGACACCTCAATAATGTTGGCAC \\
\hline $\begin{array}{l}\text { Phosphoenolpyruvate carboxykinase } 1, \\
\text { cytosolic (Pck1) }\end{array}$ & PEPCK & GAGGCCACAGCTGCTGCAGAA & GAAGAAGGGTCGCATGGCAAA \\
\hline \multicolumn{4}{|l|}{ Housekeepers } \\
\hline Peptidylprolyl isomerase A (Ppia) & Cyclophilin A & TTCCTCCTTTCACAGAATTATTCCA & CCGCCAGTGCCATTATGG \\
\hline Axin $1($ Axin 1$)$ & Axin-1 & AGTGGATCATTGAGGGAGAGA & GCCCCAGGACGCTCGAT \\
\hline Calnexin (Canx) & Calnexin & GCAGCGACCTATGATTGACAACC & GCTCCAAACCAATAGCACTGAAAGG \\
\hline
\end{tabular}

were performed using PASW Statistics 17.0 (SPSS, Chicago, IL). $P<$ 0.05 was considered statistically significant.

\section{RESULTS}

Chronic hypoxia induces major hematological adaptations. Table 2 summarizes the blood gas analyses and hematological adaptations to chronic hypoxia. As expected, arterial $\mathrm{Pa}_{2}$ and $\mathrm{Sa}_{\mathrm{O}_{2}}$ were markedly lower in mice exposed to chronic hypoxia. Furthermore, mice exposed to chronic hypoxia had lower $\mathrm{pH}$ and lower $\mathrm{HCO}_{3}{ }^{-}$but normal $\mathrm{Pa}_{\mathrm{CO}}$. Further differences included increased hematocrit, erythrocyte count, hemoglobin concentration, mean corpuscular volume, mean corpuscular hemoglobin, and a decreased mean corpuscular hemoglobin concentration in mice exposed to chronic hypoxia. In line with acidosis, the significantly higher p50(a) (oxygen tension of blood at half saturation) in mice exposed to chronic hypoxia indicates a right-shift of the oxygen-hemoglobin dissociation curve, which means a lower affinity of hemoglobin for oxygen, suggesting improved delivery of oxygen to the tissues. Also, chronic hypoxia led to an increased spleen weight by $263 \%$ $(P<0.001$, data not shown).

Recovery of food intake but lower body weight during chronic hypoxia. Directly after initiation of normobaric hypoxia, a drop in food intake was observed, which reached its nadir of $58 \%$ of starting food intake on day 3 (Fig. 1A). During days 6-10, a complete recovery of food intake was observed, and thereafter it remained stable throughout the remaining 11 days of the experiment. Starting body weights were not different between the two groups $(32.6 \pm 0.3 \mathrm{~g}$ vs. $33.1 \pm 0.6 \mathrm{~g} ; P=$ $0.55)$. During days $0-6$, body weight of mice exposed to chronic hypoxia gradually decreased by $\sim 13 \%$ (Fig. $1 B$ ). Even though their food intake reached normal values by day 10, their body weights remained stably low throughout the rest of the experiment. 
Table 2. Arterial blood gas analysis and hematological adaptations

\begin{tabular}{|c|c|c|c|}
\hline & $\begin{array}{l}\text { Normoxic Mice } \\
\quad(n=6)\end{array}$ & $\begin{array}{l}\text { Mice Exposed to } \\
\text { Chronic } \\
\text { Hypoxia }(n=6)\end{array}$ & $P$ \\
\hline $\begin{array}{l}\text { Arterial blood gas analysis } \\
\mathrm{pH}\end{array}$ & $7.28 \pm 0.01$ & $7.11 \pm 0.02$ & $<0.001$ \\
\hline $\mathrm{PaO}_{2}, \mathrm{mmHg}$ & $129.8 \pm 3.7$ & $34.3 \pm 1.6$ & $<0.001$ \\
\hline $\mathrm{PaCO}_{2}, \mathrm{mmHg}$ & $35.1 \pm 2.7$ & $35.0 \pm 1.4$ & 0.975 \\
\hline $\mathrm{HCO}_{3}^{-}, \mathrm{mmol} / \mathrm{liter}$ & $15.9 \pm 1.1$ & $10.7 \pm 0.7$ & 0.002 \\
\hline $\mathrm{SaO}_{2}, \%$ & $100 \pm 0.4$ & $24 \pm 2.4$ & $<0.001$ \\
\hline $\begin{array}{l}\text { Base excess, } \mathrm{mEq} / \mathrm{liter} \\
\text { Hematological adaptations }\end{array}$ & $-9.7 \pm 0.9$ & $-21.2 \pm 1.4$ & $<0.001$ \\
\hline Hematocrit, \% & $45 \pm 1$ & $76 \pm 1$ & $<0.001$ \\
\hline Hemoglobin, mmol/liter & $9.0 \pm 0.3$ & $14.4 \pm 0.1$ & $<0.001$ \\
\hline Erythrocytes, $\times 10^{6}$ & $10.0 \pm 0.2$ & $13.5 \pm 0.2$ & $<0.001$ \\
\hline $\mathrm{MCV}, \mathrm{fL}$ & $45.6 \pm 0.3$ & $56.1 \pm 0.8$ & $<0.001$ \\
\hline $\mathrm{MCH}, \mathrm{pg}$ & $0.91 \pm 0.01$ & $1.07 \pm 0.02$ & $<0.001$ \\
\hline $\mathrm{MCHC}, \mathrm{g} / \mathrm{dl}$ & $19.8 \pm 0.2$ & $19.0 \pm 0.3$ & 0.026 \\
\hline p50(a) & $29.7 \pm 0.4$ & $51.6 \pm 0.9$ & $<0.001$ \\
\hline
\end{tabular}

Values are means $\pm \mathrm{SE}$. MCV, mean corpuscular volume; $\mathrm{MCH}$, mean corpuscular hemoglobin, MCHC, mean corpuscular hemoglobin concentration.

Circulating levels of cytokines and adipokines. Chronic hypoxia increased plasma IL-6 and PAI-1 concentrations, whereas leptin concentrations were decreased. Plasma concentrations of TNF- $\alpha$, IL-1 $\beta$, CCL5, MCP-1, KC, and adiponectin remained unaltered after chronic hypoxia (Table 3 ).

Loss of AT and skeletal muscle mass and decreased adipocyte size after chronic hypoxia. Whereas chronic hypoxia decreased lower limb muscle weights by $10.5 \pm 2.5 \%$ (Table 4 ), the loss of AT mass was much more pronounced (Fig. 2A). The decrease in VAT was significantly greater than that of SCAT $(-65 \%$ vs. $-55 \% ; P<0.001)$. In line with this finding, adipocytes in VAT shrunk significantly more than those in SCAT after chronic hypoxia $(-52 \%$ vs. $-40 \% ; P=0.001)$ (Fig. 2B). A strong correlation was found between AT mass and adipocyte size (VAT: $r=0.935, P<0.001$; SCAT: $r=$ $0.808, P<0.001)$.

Chronic hypoxia induces upregulation of hypoxia-sensitive genes in adipose tissue. Slc2al, Vegfa, and Pfkfb3 are hypoxiainducible genes encoding glucose transporter-1 (GLUT-1), vascular endothelial growth factor-a (VEGF-A), and the glycolysis-promoting enzyme 6-phosphofructo-2-kinase/fructose-
Table 3. Circulating levels of cytokines and adipokines

\begin{tabular}{lccc}
\hline \hline & $\begin{array}{c}\text { Normoxic Mice } \\
(\boldsymbol{n}=\mathbf{6})\end{array}$ & $\begin{array}{c}\text { Mice Exposed to } \\
\text { Chronic Hypoxia } \\
(\boldsymbol{n}=\mathbf{8})\end{array}$ & \\
\hline $\mathrm{IL}-6, \mathrm{pg} / \mathrm{ml}$ & $0.46(0.37,0.87)$ & $1.12(0.72,2.45)$ & 0.044 \\
$\mathrm{TNF}-\alpha, \mathrm{pg} / \mathrm{ml}$ & $25.1(23.5,61.5)$ & $33.3(25.1,69.1)$ & 0.467 \\
$\mathrm{IL}-1 \beta, \mathrm{pg} / \mathrm{ml}$ & $27.1(15.9,36.4)$ & $25.7(15.9,35.7)$ & 0.896 \\
$\mathrm{KC}, \mathrm{pg} / \mathrm{ml}$ & $10.6(4.1,13.6)$ & $12.1(5.1,18.1)$ & 0.651 \\
$\mathrm{CCL} 5, \mathrm{pg} / \mathrm{ml}$ & $139(107,188)$ & $167(140,209)$ & 0.332 \\
$\mathrm{MCP}-1, \mathrm{pg} / \mathrm{ml}$ & $31.7(25.3,38.8)$ & $33.5(26.2,40.5)$ & 0.696 \\
$\mathrm{Leptin}, \mathrm{ng} / \mathrm{ml}$ & $8.9(6.1,11.9)$ & $4.6(4.2,5.1)$ & 0.002 \\
Adiponectin, $\mu \mathrm{g} / \mathrm{ml}$ & $31.8(27.3,38.7)$ & $32.1(27.4,43.0)$ & 0.897 \\
PAI-1, ng/ml & $1.3(1.1,1.7)$ & $2.4(2.3,3.0)$ & 0.002 \\
\hline
\end{tabular}

Values are medians and 95\% confidence intervals. IL, interleukin, TNF- $\alpha$, tumor necrosis factor- $\alpha$; KC, keratinocyte-derived chemokine; CCL5, chemokine (C-C motif) ligand 5; MCP-1, monocyte chemotactic protein-1; PAI-1, plasminogen activator-inhibitor-1.

2,6-biphosphatase 3 (PFKFB3), respectively $(22,38)$. Chronic hypoxia increased expression of Slc2al in SCAT and Vegfa and $P f k f 3 b$ in both SCAT and VAT (Fig. 3), suggesting that despite the hematological adaptations described above, oxygen delivery to AT was insufficient, resulting in a reduced AT $\mathrm{Pa}_{\mathrm{O}_{2}}$. The degree of upregulation of these genes was similar in VAT and SCAT.

Chronic hypoxia attenuates the inflammatory profile in VAT and SCAT. AT macrophages are considered to be pivotal players in adipose tissue inflammation (20). In both VAT and SCAT of mice exposed to chronic hypoxia, we found significantly lower gene expression of key markers related to macrophage presence (Emrl) and macrophage recruitment ( $\mathrm{Ccl}$ ) (Fig. 4A). This was confirmed by lower macrophage density in both VAT and SCAT (Fig. $4, B$ and $C$ ). The decreases in macrophage markers and density were not different between VAT and SCAT. CLS counts were too low to draw a firm conclusion, but tended to be lower in mice exposed to chronic hypoxia, particularly in VAT (data not shown).

In addition, gene expression of Tnf, Ill0, and Lep was lower in VAT of mice exposed to chronic hypoxia, whereas expression of Adipoq and Serpine 2 was increased (Fig. 5A). SCAT of mice exposed to chronic hypoxia was further characterized by lower expression of $I l 10$ and Lep, and an increased Serpine2 expression (Fig. 4B). The decrease in Lep and the increase in
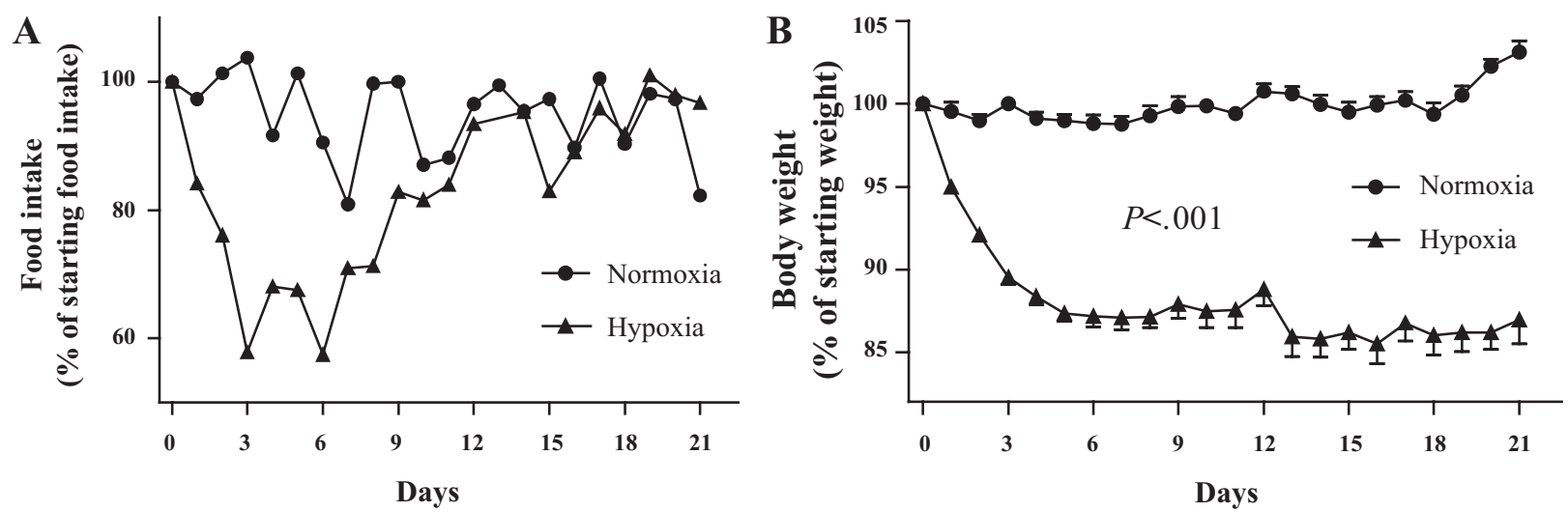

Fig. 1. Hypoxia reduces food intake and body weight, but only food intake recovers. $A$ : food intake as percentage of starting food intake. Three to four mice were housed per cage. Data represent the mean food intake per mouse, relative to day 0 . B: body weight as percentage of starting body weight. 
Table 4. Peripheral skeletal muscle weights

\begin{tabular}{|c|c|c|c|}
\hline & $\begin{array}{l}\text { Normoxic Mice } \\
\quad(n=6)\end{array}$ & $\begin{array}{l}\text { Mice Exposed to } \\
\text { Chronic } \\
\text { Hypoxia }(n=8)\end{array}$ & $P$ \\
\hline \multicolumn{4}{|l|}{ Peripheral skeletal muscle, mg } \\
\hline Gastrocnemius muscle & $317 \pm 2.2$ & $276 \pm 4.0$ & $<0.001$ \\
\hline Tibialis muscle & $117 \pm 1.3$ & $106 \pm 1.6$ & $<0.001$ \\
\hline Plantaris muscle & $41.2 \pm 0.8$ & $36.0 \pm 0.8$ & $<0.001$ \\
\hline Extensor digitorum longus muscle & $27.5 \pm 0.4$ & $24.6 \pm 0.4$ & $<0.001$ \\
\hline Soleus muscle & $21.7 \pm 0.4$ & $20.2 \pm 0.6$ & 0.096 \\
\hline
\end{tabular}

Values are means $\pm \mathrm{SE}$.

Adipoq expression were more pronounced in VAT than in SCAT. Additionally, the decrease in $1 l 10$ expression was greater in SCAT compared with that of VAT. The lower expression of $I l l b$ in mice exposed to chronic hypoxia did not reach statistical significance, and no changes were observed in Il6 expression.

Chronic hypoxia increases expression of genes involved in oxidative and lipid metabolism in AT. We found significantly higher expression of regulators and markers of oxidative metabolism in the AT of mice exposed to chronic hypoxia (Fig. $5 B)$. VAT of mice exposed to chronic hypoxia was characterized by increased Ppargcla, Ppargclb, Tfam, Adrb3, Cyc1, Ucpl, and Cidea expression. Congruently, SCAT of mice exposed to chronic hypoxia was characterized by increased Ppargclb, Adrb3, Cycl, and Ucpl expression. The expression of the adipogenesis marker Pparg and of the lipogenesis marker Srebplc were unchanged, whereas expression of the lipolysis markers Lipe and Pnpla2 was increased in both VAT and SCAT of mice exposed to chronic hypoxia (Fig. 5C). Furthermore, the expression of $P c k 1$, encoding phosphoenolpyruvate carboxykinase (PEPCK), was significantly increased in both VAT and SCAT of these mice (Fig. $5 C$ ). None of the

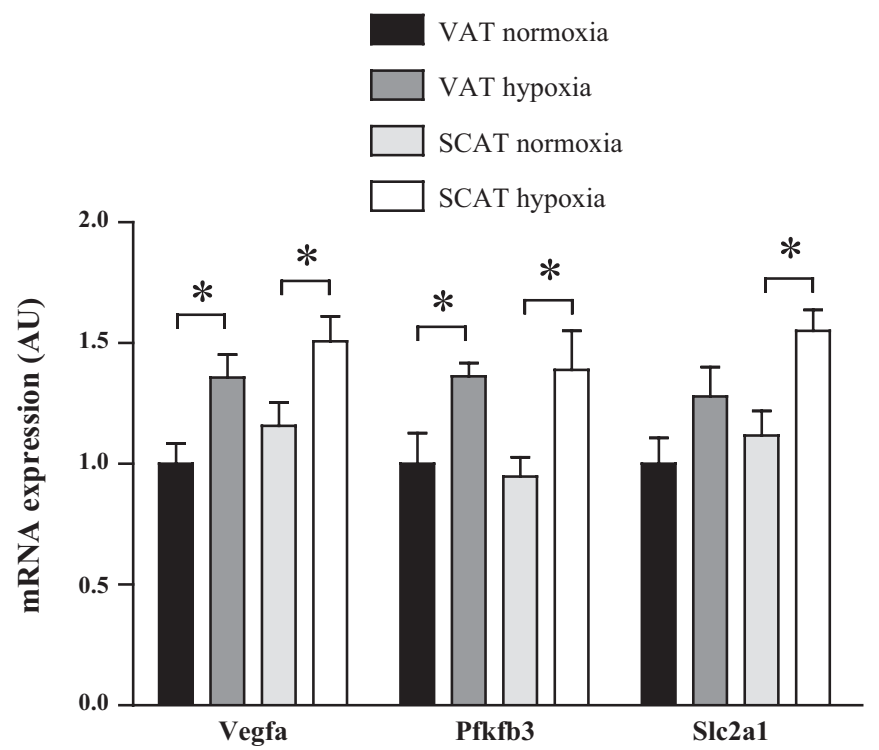

Fig. 3. Expression of hypoxia-inducible genes is increased in adipose tissue after chronic hypoxia exposure. Mice were killed after 21 days of normoxic $(n=6)$ or hypoxic $(n=8)$ conditions, and VAT and SCAT were collected. Messenger RNA expression was corrected for a stable GeNorm factor and presented relative to the levels in VAT of normoxic mice. Expression levels of Vegfa (encoding vascular endothelial growth factor-A, VEGF-A), Pfkfb3 (encoding 6-phosphofructo-2-kinase/fructose-2,6-biphosphatase 3, PFKFB3), and Slc2a1 (encoding glucose transporter 1, GLUT-1) were measured. $* P<0.05$.

chronic hypoxia-induced changes in metabolic gene expression were different between VAT and SCAT.

The alterations in metabolic gene expression after chronic hypoxia, in particular the markedly increased $U c p l$ expression, suggest browning of these white adipose tissue pads. Interestingly, we found that the adipose tissue pads were indeed characterized by a brown appearance (Fig. 6).

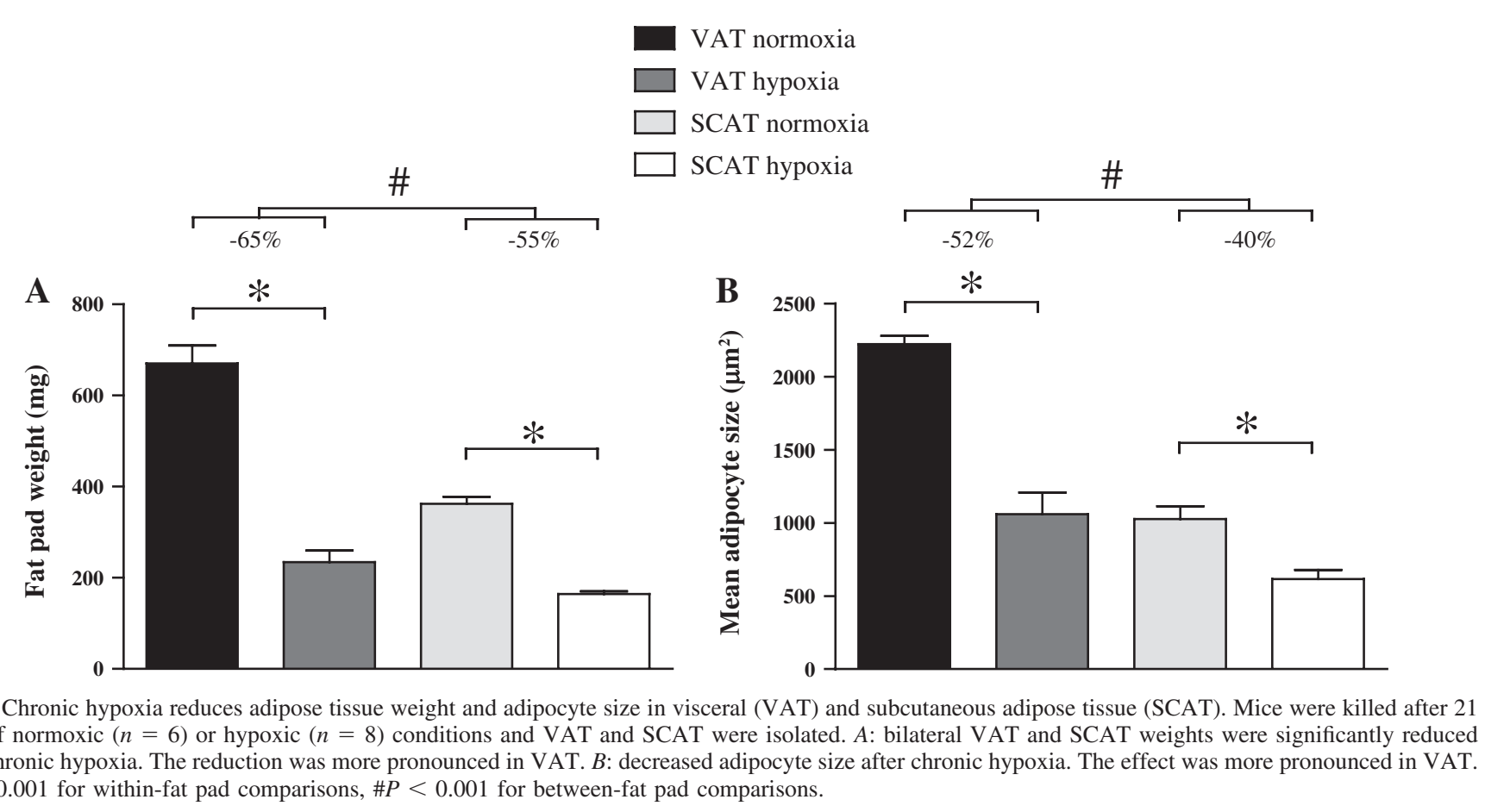


A

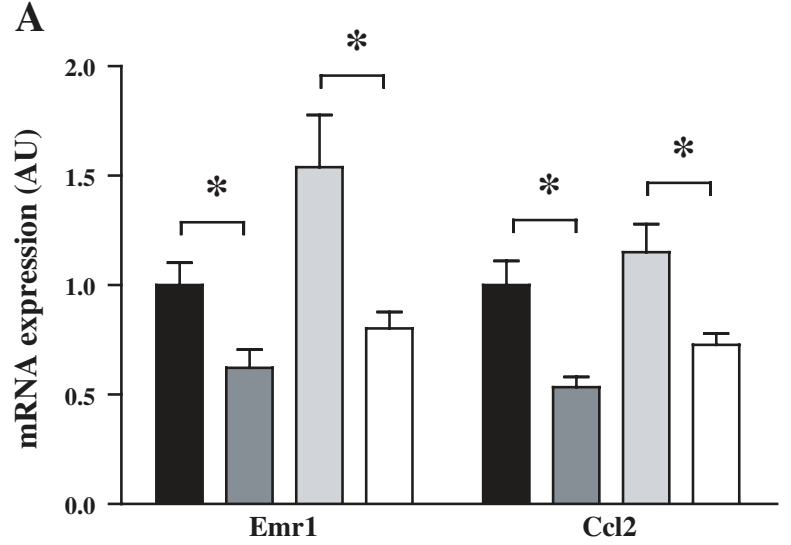

C
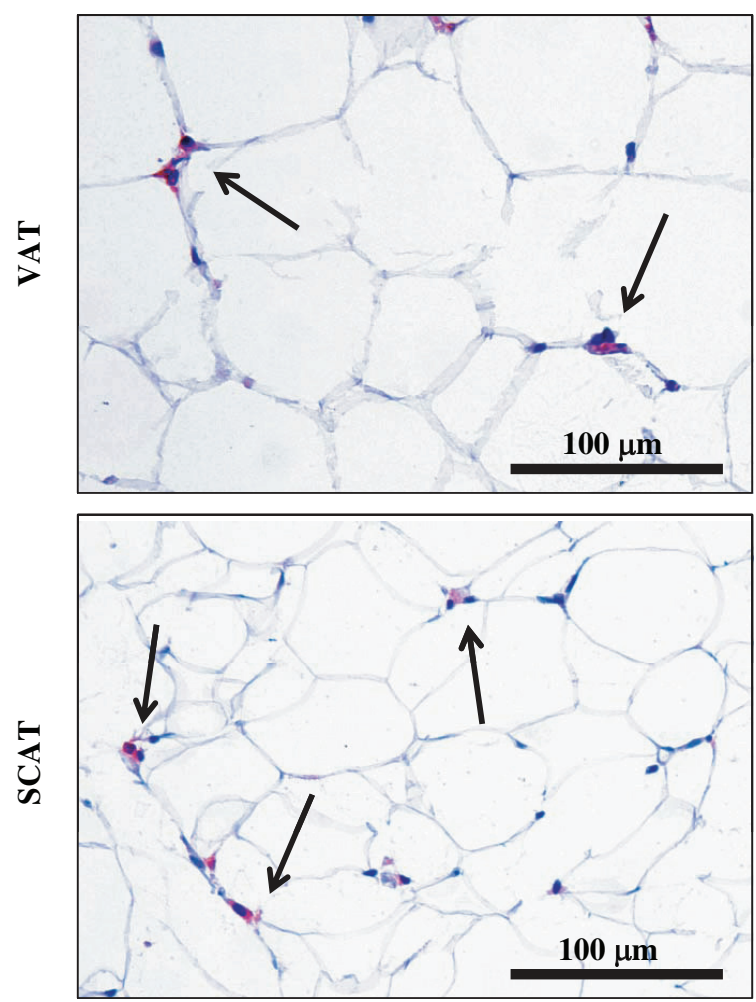

B

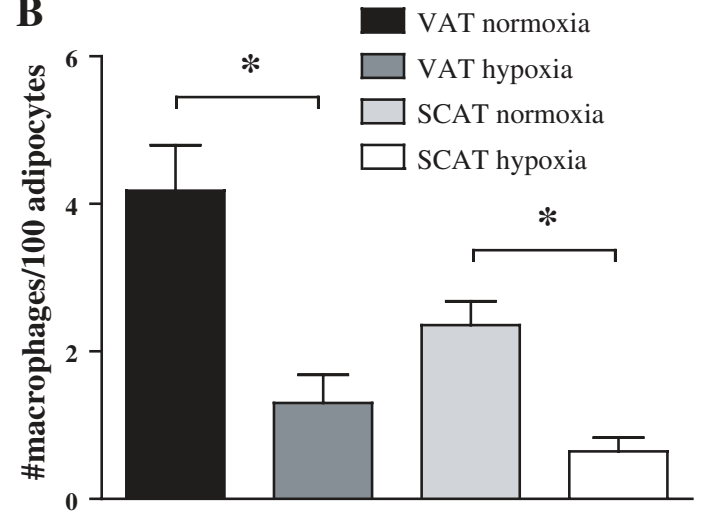

Normoxia
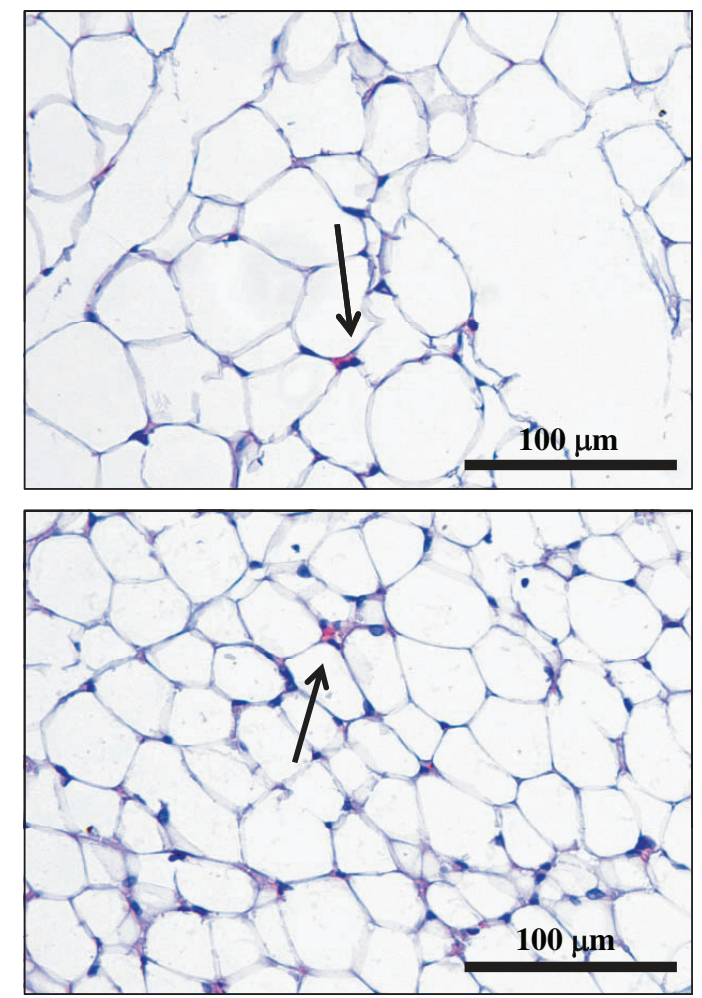

Fig. 4. Reduced adipose tissue macrophage infiltration after chronic hypoxia. Mice were killed after 21 days of normoxic $(n=6)$ or hypoxic $(n=8)$ conditions, and VAT and SCAT were collected. A: decreased mRNA levels of the macrophage markers Emr1 (encoding F4/80) and Ccl2 (encoding monocyte chemotactic protein-1, MCP-1) were observed in VAT and SCAT after chronic hypoxia. Messenger RNA expression was corrected for a stable GeNorm factor and presented relative to the levels in VAT of normoxic mice. B: adipose tissue macrophage density was assessed by quantification of immunohistochemically stained macrophages. A significant decrease was observed in adipose tissue (AT) of mice exposed to chronic hypoxia. $C$ : representative pictures illustrate decreased AT macrophage density and adipocyte size after exposure to chronic hypoxia (at 200× magnification). Arrows point toward AT macrophages.

\section{DISCUSSION}

In mice exposed to chronic hypoxia, we found consistent evidence of decreased AT inflammation and alterations in metabolic AT gene expression, suggesting increased oxidative metabolism and enhanced lipolysis. In view of the proinflammatory and oxidative-to-glycolytic shifts that have been documented after exposing adipocytes to acute and severe hypoxia in vitro, and of studies in obese mice suggesting a link between AT hypoxia and local inflammation, our findings may be unexpected. However, the present findings are in line with those in previous reports showing that abdominal subcutaneous AT $\mathrm{Pa}_{2}$ was significantly increased rather than decreased in obese insulin-resistant individuals, and was positively associated with AT gene expression of several proinflammatory markers (9). In that study, the lower AT $\mathrm{Pa}_{2}$ in obesity seemed to be due to decreased in vivo abdominal subcutaneous AT oxygen consumption, suggesting a lower metabolic rate of AT in obese subjects. Furthermore, abdominal subcutaneous AT $\mathrm{Pa}_{\mathrm{O}_{2}}$ was inversely associated with AT expression of PPARGC1A 

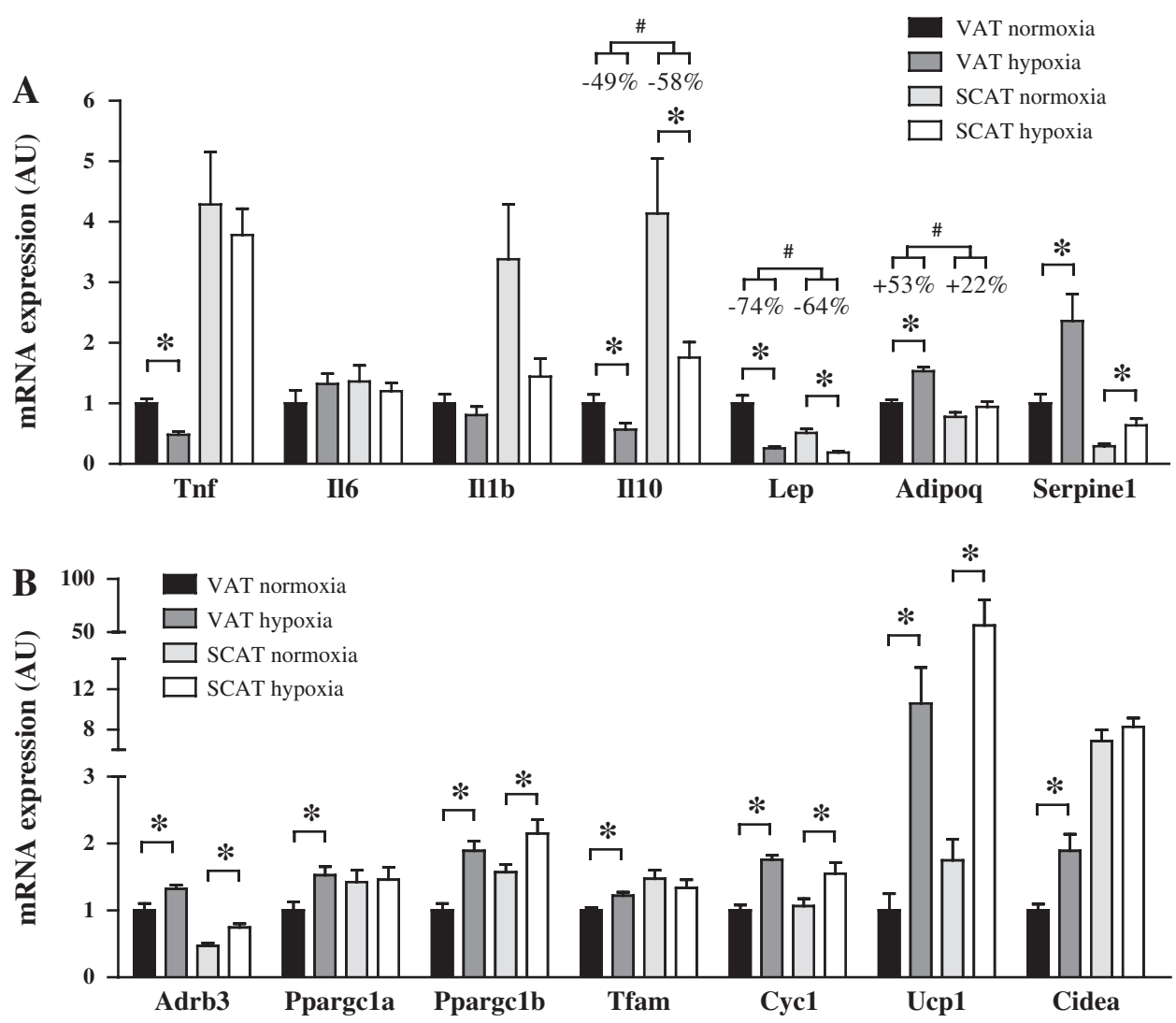

Fig. 5. Significant alterations in adipose tissue gene expression of cytokines and adipokines and of key markers of oxidative and lipid metabolism after chronic hypoxia. Mice were killed after 21 days of normoxic $(n=6)$ or hypoxic $(n=8)$ conditions, and VAT and SCAT were collected. A: mRNA levels of specific cytokines and adipokines in AT of mice exposed to normoxia or chronic hypoxia. $B$ : increased mRNA levels of regulators and markers of oxidative metabolism in AT of mice exposed to chronic hypoxia. $C$ : mRNA levels of lipolysis-related markers in adipose tissue of mice exposed to normoxia or chronic hypoxia. Messenger RNA expression was corrected for a stable GeNorm factor and presented relative to the levels in VAT of normoxic mice. $* P<0.05$ for within-fat pad comparisons, $\# P<0.05$ for between-fat pad comparisons.

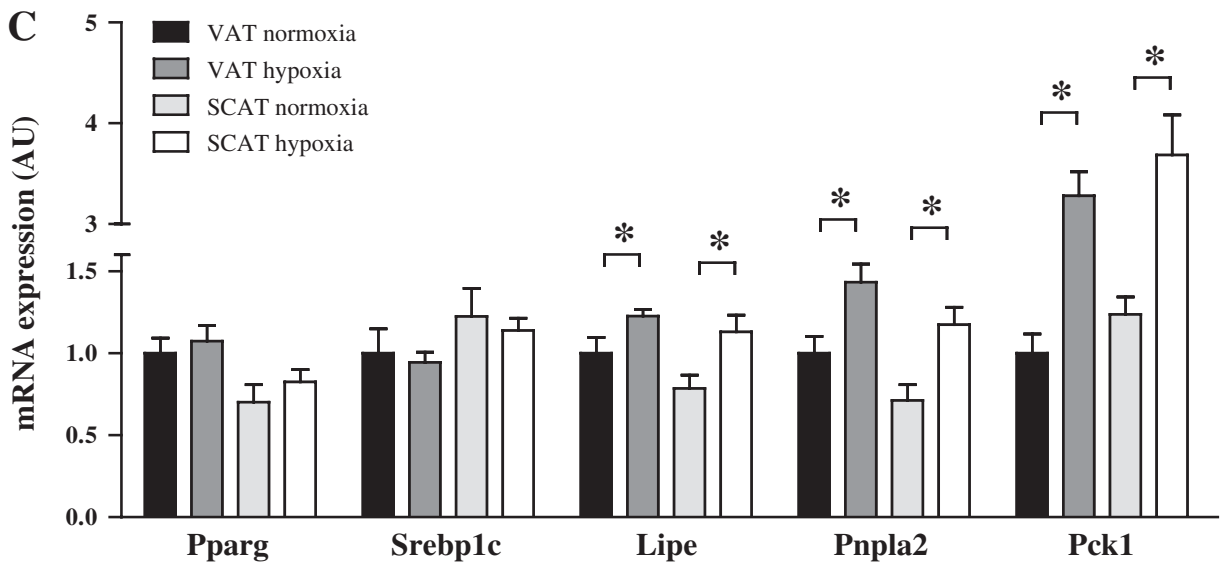

and VEGFA (9). The present data suggest that these associations may also hold in a model of chronic hypoxia. Congruently, it has recently been reported that primary human SCAT-derived adipocytes from overweight individuals displayed reduced expression of nuclear factor- $\kappa \mathrm{B}$ related genes (including CCL2), and showed a blunted response to TNF- $\alpha$ stimulation in terms of CCL2 expression and protein secretion when exposed to hypoxia (5). Our data underline the complexity of the effects of hypoxia on AT function and suggest important differences between acute and chronic effects. To the best of our knowledge, no previous study has investigated AT function after exposure to chronic hypoxia, precluding direct comparisons.

The gross phenotypical changes in mice exposed to chronic hypoxia should not be disregarded when interpret- ing AT inflammatory and metabolic alterations. Chronic hypoxia markedly reduced fat mass and, congruently, decreased adipocyte size. This may have contributed to decreased AT inflammation. Indeed, adipocyte size has been recognized as an important determinant of adipokine expression and secretion, with large adipocytes being more proinflammatory than small adipocytes (34). During the course of hypertrophy, adipocytes produce CCL2, and fatty acids released from hypertrophied adipocytes can bind Toll-like receptor 4 complex, thereby activating an inflammatory response in AT macrophages (15). Conversely, our data on smaller adipocytes, decreased AT Ccl2 and Emrl expression, and decreased AT macrophage density suggest that these mechanisms of AT macrophage infiltration and activation are significantly attenuated after chronic hypoxia. 

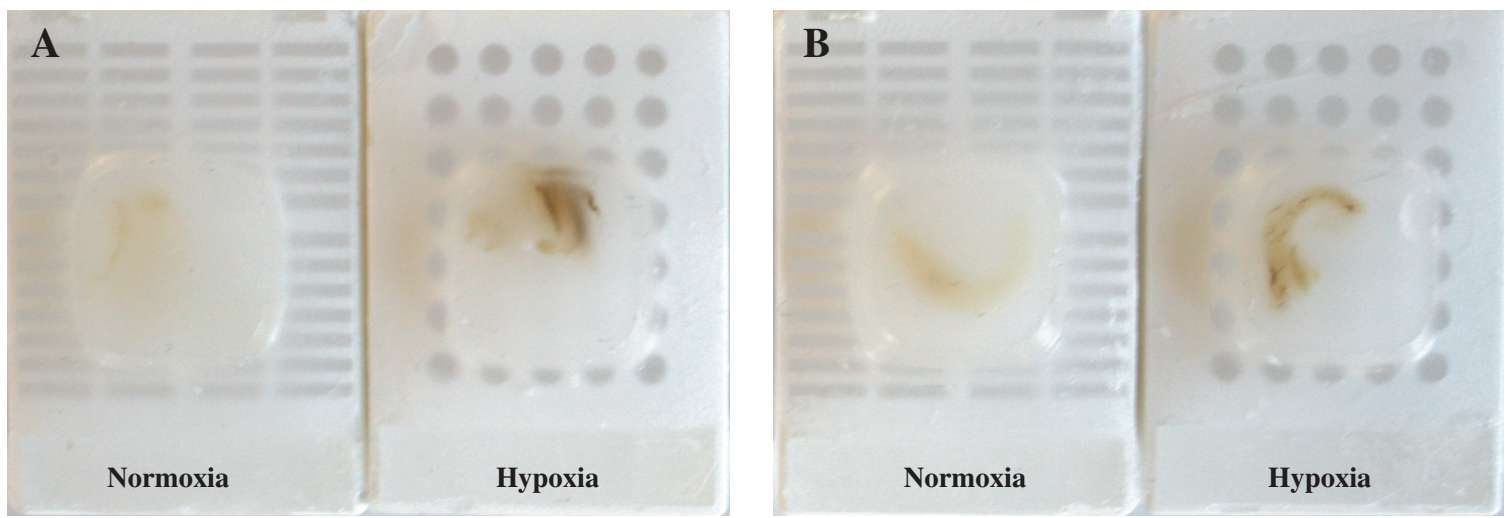

Fig. 6. Brown appearance of visceral and subcutaneous adipose tissue after chronic hypoxia. Representative adipose tissue pads of mice exposed to 21 days of normoxia or hypoxia. Photographs were taken once the tissues were embedded in paraffin. Note the brown appearance of the adipose tissue pads of mice exposed to chronic hypoxia. $A$ : visceral adipose tissue. $B$ : subcutaneous adipose tissue.

Low-grade systemic inflammation associated with elevated IL-6 has been suggested to play a pivotal role in both obesity and COPD, and AT has been considered an important contributor in both diseases $(3,40)$. It has previously been shown that sustained hypoxia results in increased levels of circulating IL-6 $(16,30)$, which is confirmed by the current data. Also, chronic hypoxia almost doubled the concentrations of circulating PAI-1, which is a main inhibitor of fibrinolysis. This is in line with a previous study (25), and with the well-known association between systemic inflammation and a prothrombotic state (4). The changes in circulating PAI-1 and leptin concentrations after chronic hypoxia were paralleled by changes in AT gene expression of these adipokines. However, AT IL-6 gene expression was unchanged and other proinflammatory markers were even decreased. This suggests that chronic hypoxia-enhanced circulating IL-6 levels and likely chronic hypoxia-induced low-grade systemic inflammation in general, are not accounted for by AT.

In our model, exposure to hypoxia initially induced significant weight loss and decreased food intake, but after 10 days, food intake completely normalized, whereas body weight remained stably low. These data suggest that a new homeostatic equilibrium was established, which is characterized by a hypermetabolic state. Interestingly, this was accompanied by major changes in AT metabolic gene expression that collectively suggest increased mitochondrial biogenesis, mitochondrial function, and lipolysis after chronic hypoxia. Given this specific pattern of metabolic gene expression, it is tempting to speculate that AT remodeling occurred via chronic stimulation of adipocytic $\beta_{3}$-adrenergic receptors $\left(\beta_{3}\right.$-AR). Indeed, nor-adrenergic remodeling of white AT is characterized by an elevation of the metabolic rate, an expansion of mitochondrial mass, and upregulation of fatty acid oxidation genes, and has even been shown to induce uncoupling protein-1 (UCP-1), which is typically a brown AT marker $(17,21)$. Hormone-sensitive lipase-mediated lipolysis has, notably, been recognized as an important component of AT remodeling following $\beta_{3}$-AR activation (21). Additionally, PEPCK (encoded by Pckl) is a key mediator of glyceroneogenesis, which involves reesterification of fatty acids to triacylglycerol serving adipocytic retention rather than secretion of fatty acids (12). In brown AT, it has been suggested that glyceroneogenesis regulates the delivery of fatty acids to the mitochondria, allowing for UCP-1 activation (12). Moreover, Pckl transcription is induced by noradrenergic stimulation in brown AT (11) and in white AT proinflammatory cytokines inhibit $P c k 1$ expression (6). $\beta_{3^{-}}$ adrenergic remodeling is induced by chronic cold exposure (17); therefore, a limitation of the present study is that we did not assess body temperature nor apply a thermoneutral environment. For these reasons, we cannot fully exclude that part of our findings can be explained by relative cold exposure in mice exposed to chronic hypoxia. Because metabolic remodeling of white AT is receiving a great deal of attention in the combat against obesity, our finding of this phenomenon coinciding with decreased AT inflammation may be relevant to the obesity field. The lower fat mass and the markedly reduced adipocyte size point toward increased lipolysis after chronic hypoxia, which is further supported by the increased gene expression of the key lipolytic enzymes HSL and ATGL, and the unchanged gene expression of the adipogenic/lipogenic markers PPAR- $\gamma$ and SREBP1c. A limitation of this study, however, is that we did not assess systemic markers of lipolysis due to limited availability of material.

In conclusion, chronic hypoxia is associated with decreased rather than increased AT inflammation, and markedly decreased fat mass and adipocyte size. Furthermore, our data indicate that chronic hypoxia is accompanied by alterations in AT metabolic gene expression, pointing toward an enhanced AT metabolic rate.

\section{DISCLOSURES}

This study was performed under the framework of the Dutch Top Institute Pharma, Project T1-201. Partners within this project are Maastricht University Medical Center, University Medical Center Groningen, University Medical Center Utrecht, GlaxoSmithKline, AstraZeneca, Nycomed, and Danone Research. Partners and Top Institute Pharma approved the manuscript. The partners had no role in the data interpretation or writing of the manuscript.

\section{AUTHOR CONTRIBUTIONS}

Author contributions: B.v.d.B., A.M.S., C.d.T., and H.R.G. conception and design of research; B.v.d.B., C.d.T., and A.W.B. performed experiments; B.v.d.B. analyzed data; B.v.d.B., A.M.S., G.H.G., and H.R.G. interpreted results of experiments; B.v.d.B. prepared figures; B.v.d.B. drafted manuscript; B.v.d.B., A.M.S., C.d.T., A.W.B., S.E.K., G.H.G., and H.R.G. approved final 
version of manuscript; A.M.S., C.d.T., S.E.K., G.H.G., and H.R.G. edited and revised manuscript.

\section{REFERENCES}

1 Buist AS, McBurnie MA, Vollmer WM, Gillespie S, Burney P, Mannino DM, Menezes AM, Sullivan SD, Lee TA, Weiss KB, Jensen RL, Marks GB, Gulsvik A, Nizankowska-Mogilnicka E. International variation in the prevalence of COPD (the BOLD Study): a populationbased prevalence study. Lancet 370: 741-750, 2007.

2. DiGirolamo M, Newby FD, Lovejoy J. Lactate production in adipose tissue: a regulated function with extra-adipose implications. FASEB $J$ 6: 2405-2412, 1992.

3. Eder K, Baffy N, Falus A, Fulop AK. The major inflammatory mediator interleukin-6 and obesity. Inflamm Res 58: 727-736, 2009.

4. Esmon CT. The interactions between inflammation and coagulation. $\mathrm{Br} \mathrm{J}$ Haematol 131: 417-430, 2005.

5. Famulla S, Horrighs A, Cramer A, Sell H, Eckel J. Hypoxia reduces the response of human adipocytes towards TNFalpha resulting in reduced NF-kappaB signaling and MCP-1 secretion. Int J Obes (Lond) 36: $986-$ 992, 2012.

6. Feingold KR, Moser A, Shigenaga JK, Grunfeld C. Inflammation inhibits the expression of phosphoenolpyruvate carboxykinase in liver and adipose tissue. Innate Immun 18: 231-240, 2012.

7. Franssen FM, O'Donnell DE, Goossens GH, Blaak EE, Schols AM. Obesity and the lung: 5. Obesity and COPD. Thorax 63: 1110-1117, 2008.

8. Goossens GH. The role of adipose tissue dysfunction in the pathogenesis of obesity-related insulin resistance. Physiol Behav 94: 206-218, 2008.

9. Goossens GH, Bizzarri A, Venteclef N, Essers Y, Cleutjens JP, Konings E, Jocken JW, Cajlakovic M, Ribitsch V, Clement K, Blaak EE. Increased adipose tissue oxygen tension in obese compared with lean men is accompanied by insulin resistance, impaired adipose tissue capillarization, and inflammation. Circulation 124: 67-76, 2011.

10. Goossens GH, Blaak EE. Adipose tissue oxygen tension: implications for chronic metabolic and inflammatory diseases. Curr Opin Clin Nutr Metab Care 15: 539-546, 2012.

11. Hahn P, Kirby LT. The effects of catecholamines, glucagon, and diet on enzyme activities in brown fat and liver of the rat. Can J Biochem 52: 739-743, 1974.

12. Hanson RW, Reshef L. Glyceroneogenesist revisited. Biochimie 85: 1199-1205, 2003

13. Helsel DR. Fabricating data: how substituting values for nondetects can ruin results, and what can be done about it. Chemosphere 65: 2434-2439, 2006

14. Hosogai N, Fukuhara A, Oshima K, Miyata Y, Tanaka S, Segawa K, Furukawa S, Tochino Y, Komuro R, Matsuda M, Shimomura I. Adipose tissue hypoxia in obesity and its impact on adipocytokine dysregulation. Diabetes 56: 901-911, 2007.

15. Itoh M, Suganami T, Hachiya R, Ogawa Y. Adipose tissue remodeling as homeostatic inflammation. Int J Inflam 2011: 720926, 2011.

16. Kozak W, Wrotek S, Walentynowicz K. Hypoxia-induced sickness behaviour. J Physiol Pharmacol 8 (57 Suppl): 35-50, 2006.

17. Lowell BB, Spiegelman BM. Towards a molecular understanding of adaptive thermogenesis. Nature 404: 652-660, 2000.

18. Lubin JH, Colt JS, Camann D, Davis S, Cerhan JR, Severson RK, Bernstein L, Hartge P. Epidemiologic evaluation of measurement data in the presence of detection limits. Environ Health Perspect 112: 1691-1696, 2004.

19. Mazzatti D, Lim FL, O'Hara A, Wood IS, Trayhurn P. A microarray analysis of the hypoxia-induced modulation of gene expression in human adipocytes. Arch Physiol Biochem 118: 112-120, 2012.

20. Morris DL, Singer K, Lumeng CN. Adipose tissue macrophages: phenotypic plasticity and diversity in lean and obese states. Curr Opin Clin Nutr Metab Care 14: 341-346, 2011.

21. Mottillo EP, Shen XJ, Granneman JG. Role of hormone-sensitive lipase in beta-adrenergic remodeling of white adipose tissue. Am J Physiol Endocrinol Metab 293: E1188-E1197, 2007.

22. Obach M, Navarro-Sabate A, Caro J, Kong X, Duran J, Gomez M, Perales JC, Ventura F, Rosa JL, Bartrons R. 6-Phosphofructo-2-kinase (pfkfb3) gene promoter contains hypoxia-inducible factor-1 binding sites necessary for transactivation in response to hypoxia. $J$ Biol Chem 279: 53562-53570, 2004

23. Pasarica M, Sereda OR, Redman LM, Albarado DC, Hymel DT, Roan LE, Rood JC, Burk DH, Smith SR. Reduced adipose tissue oxygenation in human obesity: evidence for rarefaction, macrophage chemotaxis, and inflammation without an angiogenic response. Diabetes 58: 718-725, 2009.

24. Perez de Heredia F, Wood IS, Trayhurn P. Hypoxia stimulates lactate release and modulates monocarboxylate transporter (MCT1, MCT2, and MCT4) expression in human adipocytes. Pflugers Arch 459: 509-518, 2010.

25. Pinsky DJ, Liao H, Lawson CA, Yan SF, Chen J, Carmeliet $\mathbf{P}$, Loskutoff DJ, Stern DM. Coordinated induction of plasminogen activator inhibitor-1 (PAI-1) and inhibition of plasminogen activator gene expression by hypoxia promotes pulmonary vascular fibrin deposition. $J$ Clin Invest 102: 919-928, 1998.

26. Poggi M, Engel D, Christ A, Beckers L, Wijnands E, Boon L, Driessen A, Cleutjens J, Weber C, Gerdes N, Lutgens E. CD40L deficiency ameliorates adipose tissue inflammation and metabolic manifestations of obesity in mice. Arterioscler Thromb Vasc Biol 31: 2251-2260, 2011.

27. Popkin BM. Recent dynamics suggest selected countries catching up to US obesity. Am J Clin Nutr 91: 284S-288S, 2010.

28. Quintero P, Gonzalez-Muniesa P, Garcia-Diaz DF, Martinez JA. Effects of hyperoxia exposure on metabolic markers and gene expression in 3T3-L1 adipocytes. J Physiol Biochem 68: 663-669, 2012.

29. Raguso CA, Luthy C. Nutritional status in chronic obstructive pulmonary disease: role of hypoxia. Nutrition 27: 138-143, 2011.

30. Raja KB, O Latunde-Dada G, Peters TJ, McKie AT, Simpson RJ. Role of interleukin-6 in hypoxic regulation of intestinal iron absorption. $\mathrm{Br}$ J Haematol 131: 656-662, 2005.

31. Rausch ME, Weisberg S, Vardhana P, Tortoriello DV. Obesity in C57BL/6J mice is characterized by adipose tissue hypoxia and cytotoxic T-cell infiltration. Int J Obes (Lond) 32: 451-463, 2008.

32. Sabo-Attwood T, Ramos-Nino M, Bond J, Butnor KJ, Heintz N, Gruber AD, Steele C, Taatjes DJ, Vacek P, Mossman BT. Gene expression profiles reveal increased mClca3 (Gob5) expression and mucin production in a murine model of asbestos-induced fibrogenesis. Am J Pathol 167: 1243-1256, 2005.

33. Schols AM. Pulmonary cachexia. Int J Cardiol 85: 101-110, 2002.

34. Skurk T, Alberti-Huber C, Herder C, Hauner H. Relationship between adipocyte size and adipokine expression and secretion. J Clin Endocrinol Metab 92: 1023-1033, 2007.

35. Tkacova R, Ukropec J, Skyba P, Ukropcova B, Pobeha P, Kurdiova T, Joppa P, Klimes I, Tkac I, Gasperikova D. Effects of hypoxia on adipose tissue expression of NFkappaB, IkappaBalpha, IKKgamma and IKAP in patients with chronic obstructive pulmonary disease. Cell Biochem Biophys. 2012 [Epub ahead of print].

36. Tkacova R, Ukropec J, Skyba P, Ukropcova B, Pobeha P, Kurdiova T, Joppa P, Klimes I, Tkac I, Gasperikova D. Increased adipose tissue expression of proinflammatory CD40, MKK4 and JNK in patients with very severe chronic obstructive pulmonary disease. Respiration 81 : 386393, 2011.

37. Trayhurn P. Hypoxia and adipose tissue function and dysfunction in obesity. Physiol Rev 93: 1-21, 2013.

38. Trayhurn P, Wang B, Wood IS. Hypoxia in adipose tissue: a basis for the dysregulation of tissue function in obesity? Br J Nutr 100: 227-235, 2008.

39. Trayhurn P, Wood IS. Adipokines: inflammation and the pleiotropic role of white adipose tissue. Br J Nutr 92: 347-355, 2004.

40. van den Borst B, Gosker HR, Koster A, Yu B, Kritchevsky SB, Liu Y, Meibohm B, Rice TB, Shlipak M, Yende S, Harris TB, Schols AM. The influence of abdominal visceral fat on inflammatory pathways and mortality risk in obstructive lung disease. Am J Clin Nutr 96: 516-526, 2012.

41. Vandesompele J, De Preter K, Pattyn F, Poppe B, Van Roy N, De Paepe A, Speleman F. Accurate normalization of real-time quantitative RT-PCR data by geometric averaging of multiple internal control genes. Genome Biol 3: RESEARCH0034, 2002.

42. Vozoris N, O'Donnell DE. Prevalence, risk factors, activity limitation and health care utilization of an obese, population-based sample with chronic obstructive pulmonary disease. Can Respir J 19: e18-e24, 2012.

43. Wagner PD. Possible mechanisms underlying the development of cachexia in COPD. Eur Respir J 31: 492-501, 2008.

44. Wong HL, Pfeiffer RM, Fears TR, Vermeulen R, Ji S, Rabkin CS. Reproducibility and correlations of multiplex cytokine levels in asymptomatic persons. Cancer Epidemiol Biomarkers Prev 17: 3450-3456, 2008 . 
45. Wree A, Mayer A, Westphal S, Beilfuss A, Canbay A, Schick RR, Gerken G, Vaupel P. Adipokine expression in brown and white adipocytes in response to hypoxia. J Endocrinol Invest 35: 522-527, 2012.

46. Ye J, Gao Z, Yin J, He Q. Hypoxia is a potential risk factor for chronic inflammation and adiponectin reduction in adipose tissue of ob/ob and dietary obese mice. Am J Physiol Endocrinol Metab 293: E1118-E1128, 2007.
47. Yin J, Gao Z, He Q, Zhou D, Guo Z, Ye J. Role of hypoxia in obesity-induced disorders of glucose and lipid metabolism in adipose tissue. Am J Physiol Endocrinol Metab 296: E333-E342, 2009.

48. Yu J, Shi L, Wang H, Bilan PJ, Yao Z, Samaan MC, He Q, Klip A, Niu W. Conditioned medium from hypoxia-treated adipocytes renders muscle cells insulin resistant. Eur J Cell Biol 90: 1000-1015, 2011.

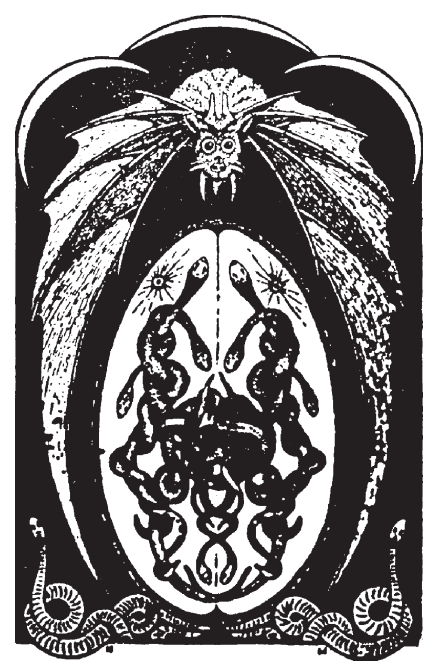

